\title{
MOTIVES FOR FOOD CHOICE AMONG SERBIAN CONSUMERS
}

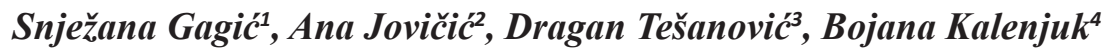

\begin{abstract}
Summary
People's motives for food choice depend on a number of very complex economic, social and individual factors. A Food Choice Questionnaire (FCQ), an instrument that measures the importance of factors underlying food choice, was used to reveal the Serbian consumers' food choice motives by survey of 450 respondents of different age groups. A confirmatory factor analysis was conducted on the motive items, using 11 factors. Previous research shows that the nutrition in Serbia is not balanced enough, and therefore the analysis of motives for food choice is considered a useful tool for the planning of more efficient public policies and interventions aimed at influencing healthier eating habits. Hence the results can be useful for researchers as well as for public institutions which deal with creating the strategy of public health or businessmen who produce and sell food products, because knowing consumer behaviour is necessary for product success on the market.
\end{abstract}

Key words: food, consumer, motives, Food Choice Questionnaire, Serbia

JEL: D91, I18, L19.

\section{Introduction}

Eating habits are formed in the past under the influence of natural and climatic factors, and local agricultural production. Today, they are changing very rapidly, and are most affected by social mega trends (Gagić et al., 2012).

In scientific and professional circles, there is no more resistance to the claim that nutrition is the most important factor which influences health. Modern society is facing an epidemic of

1 Snježana Gagić, M.Sc., Teaching Assistant, College of professional studies in management and business communication, Department of Hospitality, Sremski Karlovci, E-mail: gagicsnjezana@yahoo.com

2 Jovičić Ana, M.Sc. Research Assistant, The Geographical Institute Jovan Cvijic of the Serbian Academy of Sciences and Arts, Beograd, Đure Jakšića 9, E-mail: ana.jovicic@fondmt.rs

3 Dragan Tešanović, Ph.D., Full Professor, University of Novi Sad, Faculty of Science, Department of Geography, Tourism and Hotel Management, Novi Sad, Serbia, Trg Dositeja Obradovića 3, E-mail: tesanovic.dragan@gmail.com

4 Bojana Kalenjuk, M.Sc., Teaching Assistant, University of Novi Sad, Faculty of Science, Department of Geography, Tourism and Hotel Management, Novi Sad, Serbia, Trg Dositeja Obradovića 3, E-mail: bojanakalenjuk@yahoo.com

EP 2014 (61) 1 (41-51) 
chronicle diseases caused by bad nutrition habits and therefore, over the last years, there has been an increased interest in foods as well as in the effect of specific foods and nutrients on health (Sevak et al., 2004).

However, health is not the only factor people take into account when choosing their food. There is a set of motives significance for many people such as sensory appeal, price, ethical concern, weight control, convenience, natural content, familiarity, etc.

People perceive food as a means of satisfying different needs when making dietary choices, other than solely nutrition. Food consumption is affected by a multitude of influences. Some will use food to maintain a desirable body weight and to keep good looks; others will perceive it as a status symbol, prestige, as the shortest way for reaching satisfaction, as a means of preserving good health, etc.

Recent research in Serbia emphasizes the analysis of perceptions and attitudes of customers towards particular types of food products, for example, dairy products, (Vlahović et al., 2005), vegetables (Rodić et al., 2007), functional food (Stojanović et al., 2010), etc. However, a literature review indicates a lack of qualitative research studies on food choice motivation.

Measuring the motives behind food choice can be beneficial for a wide diversity of decisions, ranging from more successful product development and design of promotional campaigns until the planning of more efficient public policies and interventions aimed at influencing healthier eating habits (Januszewska et al., 2011). Given the data presented by the Institute of Public Health of Serbia 'Dr Milan Jovanović Batut' in 2008, which show that in Serbia, there are 54.5\% registered inhabitants who are overweight, $18.3 \%$ of which are obese and $36.2 \%$ are pre-obese, it is clear that interventions are necessary. There were $2.3 \%$ of undernourished people. It was recorded that $11.6 \%$ of children and adolescents of the age between 7 and 19 were moderately obese and 6.4\% were obese, which indicates an increase compared to 2000 , when there were $8.2 \%$ of moderately obese and $4.4 \%$ of obese children and adolescents.

Consumers are increasingly involved in the development of new products and services. Therefore it is very important to observe their desires, needs and motives so that an organization can gain a good position in the market.

The food choice questionnaire (FCQ) was used as a tool to measure the motives underlying people's selection of food (Steptoe et al., 1995). It consists of 36 questions testing in a systematic way health-related and non-health related motives of food choice. With an attempt to modify the FCQ, one more groups of items were added related to food image. It was presumed that product awareness created by the media, experts and environment occurs as a motive for food choice.

The eleven found factors appear as groups of statements related to health, mood, convenience, sensory appeal, natural content, price, weight control, familiarity, ethical concern and food image. 


\section{Materials and methods}

Participants and data collection

Questionnaires were completed by consumers in Serbia. The questionnaire consists of detailed socio-demographic characteristics of pooled samples (gender, age, education, income, occupation, settlement type), and ten dimensions were included, namely weight control, price, ethical concern, convenience, natural content, health, sensory appeal, availability, familiarity and food image.

Data collection was performed during the period from February until May, 2012. To achieve a heterogeneous sample, the questionnaire was handed out to pupils at elementary schools, high schools, students at faculty, employees and retirees in a nursing home. Participants were randomly selected. The research data are yielded from a sample of 450 consumers included 277 females and 173 males. Detailed socio-demographic characteristics of the pooled samples are provided in Table 1.

Table 1. Selected socio-demographic characteristics of the samples $(\mathrm{N}=450)$

\begin{tabular}{|c|c|c|c|}
\hline Variable & Category & $\begin{array}{l}\text { Number of } \\
\text { respondents }\end{array}$ & $\begin{array}{c}\text { Percent of } \\
\text { respondents }\end{array}$ \\
\hline \multirow{2}{*}{ Gender } & Male & 173 & 34.1 \\
\hline & Female & 277 & 54.5 \\
\hline \multirow{5}{*}{ Age } & $\leq 15$ & 61 & 13,5 \\
\hline & $16-20$ & 126 & 28.1 \\
\hline & $21-25$ & 101 & 22.4 \\
\hline & $26-35$ & 104 & 23.1 \\
\hline & $>36$ & 58 & 12.9 \\
\hline \multirow{6}{*}{ Occupation } & pupils in elementary school & 62 & 13.8 \\
\hline & pupils in high school & 94 & 20.9 \\
\hline & students & 108 & 24.0 \\
\hline & employed & 141 & 31.3 \\
\hline & unemployed & 31 & 6.9 \\
\hline & pensioners & 14 & 3.1 \\
\hline \multirow{3}{*}{ Education level } & lower & 137 & 30.4 \\
\hline & middle & 103 & 22.9 \\
\hline & higher & 210 & 46.7 \\
\hline \multirow{4}{*}{$\begin{array}{l}\text { Financial } \\
\text { situation }\end{array}$} & $\begin{array}{l}\text { Without income (students, pupils, } \\
\text { unemployed) }\end{array}$ & 246 & 54.7 \\
\hline & difficult moderate & 95 & 21.1 \\
\hline & moderate & 78 & 17.3 \\
\hline & moderate-well off & 31 & 6.9 \\
\hline \multirow{2}{*}{ Settlement type } & urban & 122 & 27.1 \\
\hline & rural & 328 & 72.9 \\
\hline
\end{tabular}

\section{Questionnaire content}

The questions were related to food in general that is consumed on a typical day. Potential motives for choosing food were almost entirely based on the Food Choice Questionnaire EP 2014 (61) 1 (41-51) 
(FCQ) as described by Steptoe et al., 1995. The food choice questionnaire has been successfully applied to numerous world's countries' populations such as British (Steptoe et al., 1995), Finnish (Lindeman, Vaananen, 2000) Uruguayan (Ares, Gambaro, 2007), Belgian (Eertmans et al., 2005; Pieniak et al., 2009), Russian (Honkanen, Frewer, 2009), French, Italian, Norwegian, Polish and Spanish (Pieniak et al., 2009), Thai (Sun, 2008), Western Balkan Countries population (Milosevic et al., 2012), Hungarian, Romanian, Philippine (Januszewska et al., 2011), Japanese, Malaysian and New Zealand (Prescott, et al., 2002) and many other studies.

The convenience factor in the original questionnaire was split into convenience and availability dimensions (Honkanen, Frewer, 2009). One more factor had been added - food image. This variable consists of the following items 'Is advertised on TV', 'Is recommended by nutrition experts', 'Is on sale in the market' and 'Is recommended by friend'. A confirmatory factor analysis was conducted on the motive items, using 11 factors.

Participants rated the importance of each of the 43 FCQ-items on a five point Likerts scale. We opted for such scale instead of the original four point scale used by Steptoe et al. (1995) in order to avoid a forced agreement or disagreement of respondents. Items were introduced with the statement: 'It is important to me that the food I eat on a typical day...' with responses ranging from 1 - 'not at all important' to 5 - very important'.

\section{Analysis and results}

\section{Item statistics}

The highest importance of individual items is given to the following: tastes well (4.38), keeps me healthy (4.08) and smells nice (4.00). On the other hand less dispersion from the mean is detected for 'Is advertised on TV' (2.42), 'Comes from countries I approve of politically' (2.59) and 'Is on sale in the market' (2.71).

Table 2. Mean and Standard Deviation for whole sample and by gender.

\begin{tabular}{|l|r|r|r|r|r|r|}
\hline \multirow{2}{*}{} & \multicolumn{2}{|c|}{ Whole sample } & \multicolumn{2}{c|}{ Male } & \multicolumn{2}{c|}{ Female } \\
\cline { 2 - 7 } & \multicolumn{1}{|c|}{ Mean } & \multicolumn{1}{c|}{ SD } & Mean & \multicolumn{1}{c|}{ SD } & \multicolumn{1}{c|}{ Mean } & \multicolumn{1}{c|}{ SD } \\
\hline Sensory appeal & 3.98 & 1.00 & 3.90 & 1.06 & 4.03 & .95 \\
\hline Health & 3.87 & 1.08 & 3.86 & 1.08 & 3.88 & 1.08 \\
\hline Availability & 3.75 & 1.11 & 3.72 & 1.06 & 3.77 & 1.15 \\
\hline Natural content & 3.74 & 1.11 & 3.62 & 1.11 & 3.81 & 1.11 \\
\hline Convenience & 3.62 & 1.16 & 3.37 & 1.21 & 3.78 & 1.10 \\
\hline Weight control & 3.58 & 1.09 & 3.31 & 1.18 & 3.76 & .99 \\
\hline Price & 3.57 & 1.02 & 3.59 & 1.02 & 3.55 & 1.02 \\
\hline Mood & 3.42 & 1.19 & 3.27 & 1.22 & 3.51 & 1.16 \\
\hline Familiarity & 3.08 & 1.24 & 3.05 & 1.21 & 3.10 & 1.26 \\
\hline Ethical concern & 2.81 & 1.19 & 2.82 & 1.19 & 2.81 & 1.20 \\
\hline Food image & 2.79 & 1.13 & 2.67 & 1.10 & 2.85 & 1.14 \\
\hline
\end{tabular}


Table 2 presents the mean ratings for each factor separately for males and females as well as for whole sample.

For the sample as a whole, the highest importance of individual subscales measured through mean scores is recorded for 'sensory appeal' (3.98) what was confirmed by results of the many qualitative interviews (Magnusson et al., 2001; Wandel, Bugge, 1997; Honkanen, Voldnes, 2006; Januszewska, Pieniak, Verbeke, 2011). Health is also second important factor in Serbia (3.87), and the third is 'Availability' (3.75). The result is in accordance with the theory of contradictions in food consumption (health vs. indulgence) developed by Leipamaa-Leskinen (2007) and it supports the whole theoretical knowledge that health is an important motivating factor in food consumption. According to Flynn, et al., 2003, the majority of individuals in Europe have adequate intakes of most nutrients. Health is also recognised as one of the most important determinants of food choice in Verbeke's, 2008 and Steptoe's et al., 1995, research.

Compared with the Steptoe et al., 1995, where the authors found that sensory appeal, health, convenience and price were the most important factors among consumers in Great Britain, there are some differences in the importance ranking of the Serbian consumers motives. First, the mood was considered far less important in Serbia than in Great Britain as well as price. Second, for Serbs the most important factors are sensory appeal, health and availability.

The lowest importance is assigned to 'ethical concern (2.77) and 'food image' (2.79) as with Eertmans et al., 2005, who analysed food choice motives across western urban populations. None of the factors in general thus appear irrelevant in motivating food choice.

There are almost no differences in the ranking of factors by gender: for males and females the most important concerns are 'sensory appeal', 'health', 'availability' and 'natural content'. Female rate convenience as more important factor than man. Considering that the variables which comprised this factor were 'Is easy to prepare', 'Can be cooked very easily' and 'Takes no time to prepare', and that cooking is a duty of women in most households in Serbia, the result is explicable. It could also be noticed that women give higher importance to the factors 'Mood' and 'Weight control', which is to be expected since women are likely to connect food and emotions, and they are more often on special diets in order to lose weight. Men find price more important compared to women.

Both males and females rate 'food image' and 'familiarity' and 'ethical concern' as the least important factors.

Confirmatory factor analysis

Before conducting a factor analysis, the adequacy of data for a factor analysis was estimated. 
Table 3. Kaiser-Meyer-Olkin Measure of Sampling Adequacy (KMO)

\begin{tabular}{|l|l|r|}
\hline \multicolumn{2}{|c|}{ KMO and Bartlett's Test } \\
\hline Kaiser-Meyer-Olkin Measure of Sampling Adequacy. & .828 \\
\hline \multirow{3}{*}{ Bartlett's Test of Sphericity } & Approx. Chi-Square & 12840.673 \\
\cline { 2 - 3 } & df & 780 \\
\cline { 2 - 3 } & Sig. & .000 \\
\hline
\end{tabular}

Table number 3 presents the value of the Kaiser-Meyer-Olkin Measure of Sampling Adequacy (KMO) which amounts to 0.83 surpassing the recommended value of 0.6. (Kaiser, 1970, p. 197) while the value of the Bartlett's Test of Sphericity (Bartlett, 1954) is significant (Sig value is lower than 0.05) indicating that the set of analysed data is adequate and/or the factor analysis is justified.

Though use of the oblique rotation 43 items of the FCQ (Steptoe et al., 1995) were factor analysed. The highest loading items were selected and shown in table 4 . The eleven factors accounted for $64.1 \%$ of the variance.

The individual item standardised factor loadings on the constructs were all significant with values ranging from 0.79 to 0.47 . Only a few items appeared to have low loadings, less than 0.60 . Hence, all the items were considered in the interpretation of the factors (Hair et al., 2006).

Table 4. Factor loadings and reliability estimates for motives for food choice

\begin{tabular}{|l|l|r|}
\hline \multicolumn{1}{|c|}{ Item name and number } & \multicolumn{1}{c|}{ Factor loadings } \\
\hline \multicolumn{2}{|c|}{ Chronbach's alpha 0.86 } \\
\hline 13 & Cheers me up & $\mathbf{. 7 1}$ \\
\hline 31 & Makes me feel good & $\mathbf{. 7 1}$ \\
\hline 24 & Keeps me awake/alert & $\mathbf{. 6 9}$ \\
\hline 34 & Helps me cope with life & $\mathbf{. 6 4}$ \\
\hline 26 & Helps me relax & $\mathbf{. 6 3}$ \\
\hline 16 & Helps me cope with stress & $\mathbf{. 5 5}$ \\
\hline & & Health \\
& & Chronbach's alpha $\mathbf{0 . 8 4}$ \\
\hline 22 & Contains a lot of vitamins and minerals & $\mathbf{. 7 7}$ \\
\hline 29 & Keeps me healthy & $\mathbf{. 7 5}$ \\
\hline 30 & Is good for my skin/teeth/hair/nails etc. & $\mathbf{. 6 6}$ \\
\hline 10 & Is nutritious & $\mathbf{. 6 1}$ \\
\hline 27 & Is high in protein & $\mathbf{. 5 7}$ \\
\hline 9 & Is high in fibre & $\mathbf{5 0}$ \\
\hline & & Familiarity \\
& & Chronbach's alpha $\mathbf{0 . 8 1}$ \\
\hline 8 & Is familiar & $\mathbf{. 7 0}$ \\
\hline 33 & Is what I usually eat & $\mathbf{. 6 3}$ \\
\hline 21 & Is like the food I ate when I was a child & $\mathbf{. 5 1}$ \\
\hline
\end{tabular}




\begin{tabular}{|c|c|c|}
\hline \multicolumn{2}{|r|}{ Item name and number } & Factor loadings \\
\hline & & \multirow{2}{*}{$\begin{array}{r}\text { Ethical concern } \\
\text { Chronbach's alpha } \mathbf{0 . 8 4} \\
\end{array}$} \\
\hline & & \\
\hline 19 & Is packaged in an environmentally friendly way & .61 \\
\hline 20 & Comes from countries I approve of politically & .55 \\
\hline \multirow[t]{3}{*}{32} & Has the country of origin clearly marked & .47 \\
\hline & & \multirow{2}{*}{$\begin{array}{r}\text { Natural content } \\
\text { Chronbach's alpha } \mathbf{0 . 8 6}\end{array}$} \\
\hline & & \\
\hline 2 & Contains no additives & .78 \\
\hline 5 & Contains natural ingredients & .70 \\
\hline \multirow[t]{2}{*}{23} & Contains no artificial ingredients & .66 \\
\hline & & $\begin{array}{r}\text { Sensory appeal } \\
\text { Chronbach's alpha } 0.80\end{array}$ \\
\hline 4 & Tastes well & .79 \\
\hline 14 & Smells nice & .67 \\
\hline 18 & Has a pleasant texture & .56 \\
\hline \multirow[t]{3}{*}{25} & Looks nice & .54 \\
\hline & & \multirow{2}{*}{$\begin{array}{r}\text { Food image } \\
\text { Chronbach's alpha } 0.79\end{array}$} \\
\hline & & \\
\hline 37 & Is advertised on TV & .64 \\
\hline 38 & Is recommended by nutrition experts & .63 \\
\hline 39 & Is on sale in the market & .58 \\
\hline \multirow[t]{2}{*}{40} & Is recommended by friend & .54 \\
\hline & & $\begin{array}{l}\text { Preparation convenience } \\
\text { Chronbach's alpha } \mathbf{0 . 8 2}\end{array}$ \\
\hline 1 & Is easy to prepare & .79 \\
\hline 15 & Can be cooked very easily & .68 \\
\hline \multirow[t]{3}{*}{28} & Takes no time to prepare & .58 \\
\hline & & \multirow{2}{*}{$\begin{array}{r}\text { Price } \\
\text { Chronbach's alpha } 0.78\end{array}$} \\
\hline & & \\
\hline 6 & Is not expensive & .70 \\
\hline 12 & Is good value for money & .62 \\
\hline \multirow[t]{2}{*}{36} & Is cheap & .57 \\
\hline & & $\begin{array}{r}\text { Weight control } \\
\text { Chronbach's alpha } 0.81\end{array}$ \\
\hline 3 & Is low in calories & .70 \\
\hline 7 & Is low in fat & .66 \\
\hline \multirow[t]{3}{*}{17} & Helps me control my weight & .58 \\
\hline & & \multirow{2}{*}{$\begin{array}{r}\text { Availability } \\
\text { Chronbach's alpha } 0.76\end{array}$} \\
\hline & & \\
\hline 11 & Is easily available in shops and supermarkets & .62 \\
\hline 35 & Can be bought in shops close to where I live or work & .59 \\
\hline
\end{tabular}

Extraction Method: Principal Component Analysis.

Rotation Method: Oblimin with Kaiser Normalization.

a. Rotation converged in 9 iterations.

The reliability of the overall FCQ typology in our study is very high. Measurement scale reliability is assessed by the most frequently used indicator of internal consistency, the 
Cronbach's Alpha coefficient. The internal consistency of the FCQ factors was high, with Cronbach scores as follows: 0.86 for 'Mood', 0.84 for 'Health', 0.81 for 'Familiarity', 0.84 for 'Ethical concern', 0.86 for 'Natural content', 0.80 for 'Sensory appeal', 0.79 for 'Food image', 0.82 for 'Preparation convenience', 0.78 for 'Price', 0.81 for 'Weight control' and 0.76 for 'Availability'showing a very good reliability and internal consistency of the scale for the subject sample. Although the availability dimension was composed of only two items, those two items had consistently high loadings; thus this dimension was retained in the final factor structure.

\section{Conclusion}

Empirical data of the present research support the robustness of the original 36-item FCQ. Factor analysis distinguished all nine factors from the original questionnaire (Steptoe et al., 1995), as well as two additional - availability and food image.

The results indicate that sensory appeal is the most important factor among the Serbian consumers. This result confirms the original study on the British population and corresponds to the findings on New Zealanders with European origin (Prescott et al., 2002). Our research also shows that health, availability, natural content and convenience are among the five most important factors shaping food choice in Serbia.

Despite the fact that the last decade of the last century in Serbia was marked by wars, international sanctions and negative consequences which they produced, leading to social instability and the decline in purchasing power, the price was ranked as the seventh out of eleven observed factors.

Compared to the results from the normative Steptoe et al., 1995, sample, the Serbian consumers seem to attach high importance to more or less the same motivational dimensions such as sensory appeal, health and convenience. However, the importance assigned to natural content of food is the higher than it was almost two decades ago since the original Steptoe et al., 1995, research was conducted. It is the fact that the consumer becomes more conscious of nutrition and food ingredients than ever before and they are closer to food safety-related issues.

Finally, the least important food choice factors found in studies of Steptoe et al., 1995, are in line with our findings. Familiarity and ethical concern were the least important motives while choosing food. Obviously, Serbian consumers did not care about ethical issues, at least those implicated in the FCQ, i.e. country of origin, labelling and environmentally friendly package.

Given that the factor 'food image' was ranked as the last in the list of motives for food choice, the initial assumption that the food perception which consumers acquire through the media or their environment is an important motive for the choice is rejected.

These results can improve the efficacy of communication strategies for nutrition/health policy, and they can be very useful information for creating the strategy for introducing food products to Serbian market. 


\section{Literature}

1. Ares, G., Gambaro, A. (2007): Influence of gender, age and motives underlying food choice on perceived healthiness and willingness to try functional foods, Appetite, vol. 49, pp. 148-158.

2. Bartlett, M. S. (1954): A note on the multiplying factors for various chi square approximations, Journal of the Royal Statistical Society, vol. 16 (Series B), pp. 296-298.

3. Eertmans, A., Victoir, A., Vansant, G., Vanden Bergh, O. (2005): Food-related personality traits, food choice motives and food intake. Mediator and moderator relationships, Food Quality and Preference, vol. 16(8), pp. 714-726.

4. Flynn, A., Moreiras, O., Stehle, P., Fletcher, R., Müller, D., Rolland, V. (2003): Vitamins and minerals: A model for safe addition to foods, European Journal of Nutrition, vol. 42, pp. 118-130

5. Gagić, S. Jovičić, A. Tešanović, D., Popov-Raljić, J. (2012): The structure and development of the offer offast food restaurant chains in Serbia, Proceedings - 1st Belgrade International Tourism Conference 2012: Contemporary Tourism - Wishes and Opportunities, Belgrade, March 22-24, pp. 559-659.

6. Hair, J., Black, W., Babin, B., Anderson, R., Tatham, R. (2006): Multivariate data analysis, New Jersey, Pearson Education Inc.

7. Honkanen, P., Frewer, L. (2009): Russian consumers' motives for food choice, Appetite, vol. 52, pp. 363-371.

8. Honkanen, P., Voldnes, G. (2006): Russian consumers'food habits, Report 27/2006, Troms: Fiskeriforskning.

9. Institute of Public Health of Serbia 'Dr Milan Jovanović Batut', Serbian Residents' Health, Analytical Study 1997-2007, Beograd, 2008:45, Serbian.

10. Januszewska, R., Pieniak ,Z., Verbeke, W. (2011): Food choice questionnaire revisited in four countries. Does it still measure the same?, Appetite, vol. 57, pp. 94-98.

11. Kaiser, H. (1970): A second generation Little Jiffy, Psychometrika, vol. 35, pp. 401-415.

12. Kaiser, H. (1974): An index of factorial simplicity, Psychometrika, vol. 39, pp. 31-36.

13. Leipamaa-Leskinen, H. (2007): Contradictions in food consumption, International Journal of Consumer Studies, vol. 31, pp. 597-602.

14. Lindeman, M., Vaananen, M. (2000): Measurement of ethical food choice motives, Appetite, vol. 34(1), pp. 55-59.

15. Magnusson, M. K., Arvola, A., Hursti, U. K. K., Aberg, L., Sjoden, P. O. (2001): Attitudes towards organic foods among Swedish consumers, British Food Journal, vol. 103, pp. 209-226.

16. Miloševic, J., Zezelj, I., Gorton, M., Barjolle, D. (2012): Understanding the motives for food choice in Western Balkan Countries, Appetite, vol. 58, pp. 205-214.

17.Pieniak, Z., Verbeke, W., Vanhonacker, F., Guerrero, L., Hersleth, M. (2009): Association between traditional food consumption and motives for food choice in six European 
countries, Appetite, vol. 53, pp. 101-108.

18. Prescott, J., Young, O., O’Neill, L., Yau, N. J. N., Stevens, R. (2002): Motives for food choice. A comparison of consumers from Japan, Taiwan, Malaysia and New Zealand, Food Quality and Preference, vol. 13(7-8), pp. 489-495.

19. Rodić, V., Vlahović, B., Popović, Z. (2007): Consumers attitudes towards marinated and pasteurized vegetable, Economics of Agriculture, vol. 54, no. 4, pp. 495-505.

20. Sevak, L., Mangtani, P., McCormack, V., Bhakta, D., Kassam-Khamis, T., Silva, I. (2004): Validation of a food frequency questionnaire to assess macro- and micro-nutrient intake among South Asians in the United Kingdom, European Journal of Nutrition, vol. 43, pp. $160-168$.

21. Steptoe, A., Pollard, T. M., Wardle, J. (1995): The development of a measure of the motives underlying the selection of food: the Food Choice Questionnaire, Appetite, vol. 25, pp. 267-284.

22. Stojanovic, Z., Ognjanov, G., Dragutinovic-Mitrovic, R. (2010): Health claimed products and consumer attitudes in Balkan countries, Seminar Consumer Attitudes to food quality products in Southern Europe, Book of Abstracts of the 61st Annual Meeting of EAAP, Heraklion, Crete Islands, Greece, August 23-27, p. 332.

23. Sun, Y. C (2008): Health concern, food choice motives, and attitudes toward healthy eating: The mediating role of food choice motives, Appetite, vol. 51, pp. 42-49

24. Verbeke, W. (2008): Impact of communication on consumers 'food choices, proceeding of the Nutrition Society, vol. 67, pp. 281-288.

25. Vlahović, B., Radojević, V., Pavlović, M. (2005): Trapist cheese consumption analysis, Economics of Agriculture, vol. 52, no. 3, pp. 401-411.

26. Wandel, M., Bugge, A. (1997): Environmental concern in consumer evaluation of food quality, Food Quality and Preference, vol. 8, pp. 19-26. 


\title{
MOTIVI ZA ODABIR HRANE KOD POTROŠAČA U SRBIJI
}

\author{
Snježana Gagič́, Ana Jovičičć, Dragan Tešanovićc ${ }^{7}$, Bojana Kalenjuk ${ }^{8}$
}

\begin{abstract}
Rezime
Motivi ljudi za odabir hrane zavise od niza veoma složenih ekonomskih, socijalnih $i$ individualnih faktora. Upitnik o izboru hrane (Food Choice Questionnaire), korišćen je kao instrument koji identifikuje faktore koji utiču na odabir hrane kod srpskih potrošača razlicitih starosnih grupa na uzorku od 450 ispitanika. Konfirmatornom faktorskom analizom izdvojeno je jedanaest faktora. Prethodna istraživanja ukazuju da ishrana u Srbiji nije dovoljno uravnotežena, stoga se analiza motiva za odabir hrane smatra korisnom za planiranje efikasnijih aktivnosti koje imaju za cilj unapređenje navika u ishrani. S tim u vezi, rezultati mogu biti korisni za istraživače, javne institucije koje se bave izradom strategije javnog zdravlja ili za privrednike koji proizvode i prodaju prehrambene proizvode zbog neophodnosti poznavanja potreba potrošača za uspeh proizvoda na tržištu.
\end{abstract}

Ključne reči: hrana, potrošači, motivi, FCQ upitnik, Srbija.

5 Snježana Gagić, M.Sc., Asistent, Visoka škola strukovnih studija za menadžment i poslovne komunikacije u Sremskim Karlovcima, E-mail: gagicsnjezana@yahoo.com

6 Ana Jovičić, M.Sc. Istraživač na projektu, Geografski institut Jovan Cvijić SANU, Beograd, E-mail: ana.jovicic@fondmt.rs

7 Dragan Tešanović, Redovni profesor, Univerzitet u Novom Sadu, Prirodno-matematički fakultet, Departman za geografiju, turizam i hotelijerstvo, E-mail: tesanovic.dragan@gmail.com

8 Bojana Kalenjuk, M.Sc., Asistent, Univerzitet u Novom Sadu, Prirodno-matematički fakultet, Departman za geografiju, turizam i hotelijerstvo, E-mail: bojanakalenjuk@yahoo.com

EP 2014 (61) 1 (41-51) 
